\title{
Issues Occurrence of Career Success Among Female Engineers
}

\author{
Amalia Madihie $^{1 *}$ and Rose Amira Siman ${ }^{1}$
}

${ }^{1}$ Universiti Malaysia Sarawak, 94300 Kota Samarahan, Sarawak, Malaysia

\begin{abstract}
This research aims to identify the issues among female engineers in the perspective of their career success. The issues that were identified are work-life balance, gender stereotyping and slow progression on the career success. The research design is a qualitative approach by in-depth interview. The research design which consisted of ten items aimed to explore female engineers' satisfaction of working in the construction industry, unequal employment in the workplace, persistent problems in managing work-life balance, the role of gender in developing career success and also factors that positively and negatively affect the retention of female engineers in the construction industry. Five participants were recruited from various construction companies in Malaysia. Four of them were interviewed via phone calls and one via electronic mail. The findings from this research show that work-life balance issue is the main issue. Other issues include gender stereotype, nature of work and the competition among male and female engineers. From these findings, one recommendation is that the top management of an organization can provide full support to the employees so that they can be more productive in the workplace and are able to balance their work and nonwork responsibilities.
\end{abstract}

Keywords: Female engineers, construction industry, career success, work-life balance, gender stereotyping

\section{BACKGROUND OF STUDY}

The number of women entering into

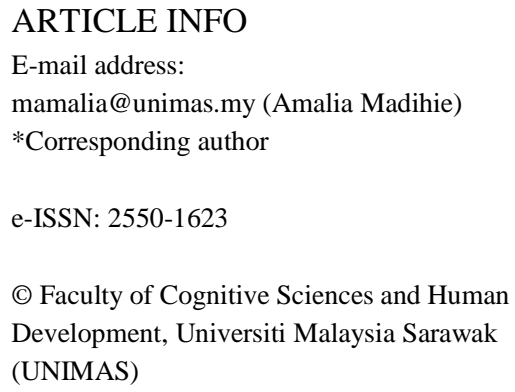

E-mail address:

mamalia@unimas.my (Amalia Madihie)

*Corresponding author

e-ISSN: 2550-1623

(C) Faculty of Cognitive Sciences and Human Development, Universiti Malaysia Sarawak (UNIMAS)

career occupation has extremely increased since the beginning of 1960's. Even though the number of women and men participation in the workforce is quite similar, the number of women entering the workforce has dropped. In the year 2011, the number of women that entered the workforce in Malaysia was at the rate of $47.9 \%$ (Department of Statistics Malaysia, 2012) and this rate of $44 \%$ to $47 \%$ has been the same for 
the last three decades (the Ministry of women, Family and Community Development and the United Nation Development Programme, 2014). Some of the stereotype thinking is that the roles of women are only restricted to housework, taking care of the children, doing all the chores etc.

Construction work by its nature is known for heavy, tough, dirty work and much of the work involves machinery or manual work. For a long time, this field has been dominated by male employees. Surprisingly, the way how women clarify and negotiate with their professional identities in the male-dominated work field has increased the number of women getting involved in this sector (Kyriakidou, 2011). However, in 2004, only nine percent of women workforces represented the total employment in the United Kingdom within the construction industry (Office of National Statistic as cited in Dainty \& Lingard, 2006). The small percentage of women workforce appears to be deliberately constituted in the construction industry as perceptions, like women are not fixed in the construction because of the heavy work for them to carry out, seem to persist (English, Haupt, \& Smallwood, 2006).

The number of women participation in the workforce for the non-traditional field in Malaysia is low compared to the number of women participation in the traditional field. Courses like teachers, nurses and administrators are more preferred by female students in the universities compared to the technical courses like engineering and medicine (Siti
Hanisah Tapsir \& Norliza Mohd Noor, 2015). According to Fielden, Davidson, Gale and Davey (2001), women were more significant for jobs like clerks, secretaries, administrative personnel. Perceptions such as women cannot do men's work like in the construction area still exist. Despite the fact that there are more female graduates, only a very small number of them managed to fill up top positions in the industries (Fernando, Amaratunga, \& Haigh, 2014) while others remained under-represented in the construction industries (Dainty \& Lingard, 2006). Fielden and colleagues, (2001) added that this had clearly proved that women were not only underrepresented within the industry but that their distribution throughout the industry was highly skewed, with almost twothirds working in secretarial or clerical roles (p. 293). Srivastava (1992) in her study added that women employees were not given appropriate experiences in this field of work resulting in low self-esteem to get themselves involved in the construction industry.

Female engineers in the construction industry faced various forms of challenges and discrimination. According to Salman Azhar and Amos Griffin (2014), some of the challenges that women employees faced in the engineering field are discrimination on the perceptions of women's skills and capabilities in doing a male-dominance job, and this has led to the slow career progression of women employees. Salman Azhar and Amos Griffin also stated that female engineers have problems in balancing their commitments between work and family. In 
order to maintain their positions in the male-dominated construction industry, female engineers only have three choices which are to act like a man or have lower goals and expect only secondary position or give up and move on to work elsewhere (Dainty, Neale, \& Bagilhole, 2000). These social norms have discouraged female engineers from pursuing or developing their careers in the engineering sector (Salman Azhar \& Amos Griffin, 2014). These challenges that most of the female engineers face in the construction industry have brought on discrimination among them and have led to occupational segregation by gender in the workplace.

Some literature has mentioned that female engineers who worked in the construction industry found themselves to be survivors facing issues like prejudice, isolation and also discrimination in terms of support from peers (Husna Johari, Norsiah Mat, Norazuwa Mat, Siti Norezam Othman, \& Aini Hayati Mohamed, 2013). This is due to the stereotype thinking that engineering or constructions are not for women (Maimunah Ismail \& Mariani Ibrahim, 2008). Thus, this research is focused on the career advancement or career success of women employees in the construction industry. From a general perspective, the purpose of this study is to find out the issues that are faced by female employees in developing their careers in this industry. This research also aims to see whether gender plays an important aspect for an employer to employ a worker in the engineering field. This study also shows how equality employment approaches between male and female workers are implemented in the organization.

Women face difficulties in achieving career success because they have different values and attitudes compared to male employees (Eagly \& Carli as cited in Madegwa, 2011, p. 17). Women employees often have higher standards of performance level than men in evaluating their performance appraisal (Madegwa, 2011). Research shows women who have higher performance ratings than men tend to be promoted (Lyness \& Heilman as cited in Magedwa, 2011, p. 17), while other research shows that women employees who are not performing above and beyond their male colleagues in their performance appraisal tend be penalized (Madegwa, 2011).

Tharenou (1999) explained that slow mobility among women employees in an organization are that gender differences invest in different human capital result. Women tend to receive a lower advancement in terms of rewards, payment, and job status because they make fewer investments than men. The idea of women who are under-represented in the higher level in the hierarchy authority or higher salary position is known as the glass ceiling effect (European Foundation for the Improvement of Living and Working Conditions, 2007). Fielden and colleagues (2001) stated that the engineering industry has not formally acknowledged that the underrepresentation of women is an important issue (p. 294). The glass ceiling concept is the barrier of bad impression and prej- 
udices towards women's capabilities that is not allowing them to move from one position to another in the organization hierarchy.

Kolade and Kehinde (2013) added that perceptions like women are physically not capable of doing men's work indirectly has discriminated them from entering the engineering sector. Bias in the form of organizational structure and policies, as well as in the roles of women employees in the family, have been seen as the threats to women from receiving career advancement. Heilman (2001) stated that being competent is not enough in order for women to receive the same career advancement as men in organizational level. Women are said to have a slow career progression and it has become one of the factors that brings on gender discrimination among female workers (Madegwa, 2011).

Madegwa added that women are not compatible of getting a promotion in the organization due to some of their traits and behaviors that lead to the slow progression of their career. For example, women tend to value compassion more highly than do men, which can be in direct conflict with a highly competitive culture (Madegwa, 2011, p. 17). Although the number of women employees increase, gender segregation has remained a significant problem in women's career development. Women are perceived to receive both horizontal and vertical segregations when they are isolated from senior positions and are prejudiced on their roles and functions in the organization (European Foundation for the Improvement of Living and Working Conditions, 2007). Dainty and Lingard (2006) stated that despite the fact that jobs like site-based technical and managerial jobs are important for career development, women employees are still under-represented in the engineering industry.

According to Fouad and colleagues (2012), some of the engineering graduates did not enter the engineering sector because of perceptions like engineering as being inflexible and the workplace culture is not supportive for women. The European Foundation for the Improvement of Living and Working Conditions (2007) reported that women employees in Austria and United Kingdom faced the problem of demotion to a lower position after they came back from maternity leave. This is clearly against the act which can lead to discrimination. Other research also supported this finding and said that women face problems to do with credibility, blocked occupational mobility, discrimination and fixed stereotypes (European Foundation for the Improvement of Living and Working Conditions, 2007, p. 17).

The concept of work-life balance has always been an issue to career women ever since women are involved in the workforce. Typically, many of them assume that balance is a gendered concept issue that only applies to women employees. The concept of work-life balance is implied to the employees that are concerned with their working life quality and also family life quality (Farah Mukhtar, 2012). The performance 
of an employee would remain stagnant if the employee chooses to increase both of the work and family balance. Thompson, Beauvais \& Lyness (1999) outlined three main types of conflict that are faced by employees coping with work-life balance issues: time-based conflict, strain-based conflict and behaviour-based conflict. These conflicts act as the decision factors by the employees on which of the balances should they take care of- the priority between work and family; personal understanding and emotional strain and also the process of choosing either or both (Thompson and colleagues, 1999).

The stereotyping thinking has aroused indirect discrimination among female workers in this sector. One of the indirect discriminations that exists in this industry is that life cycle and family needs influence the decision-making process of women employees which could then restrict their development progress to stay in the construction industry (Dainty \& Lingard, 2006). Farah Mukhtar (2012) added that work-family balance has given a negative impact on the changes in traditional gender roles, coupled with dual career families and single heads of households (p. 12). This is due to the problems in dealing with the ways the employee tries to balance both of the employment fulfillment and personal responsibilities but did not manage to overlap the situations (Farah Mukhtar, 2012).

Farah Mukhtar added that these conflicts arise when an employee is not able to choose and be fair to either or both of the work and family balance. These situa- tions could lead to a negative impact on the performance level of both individual and also the organization as it slows down and affect the development process within the workplace. Farah Mukhtar (2012) added that male employees spent more time in work than personal activities compared to female employees. Altucher and William (2003) also added that society tends to see family as a personal matter that needs to be resolved by each of the family members alone. These gender role stereotypes have led to the expectation that women are more effective than men (Madegwa, 2011) because they tend to have the feeling of wanting a family more than stay in the workforce. Therefore, the career path of women employees dropped due to the negative result of the gender role incongruent behaviour (Stratham as cited in Madegwa, 2011, p. 15). Madegwa added that the internal or personal factor of women employees has resulted in their slow progression in the management. In the meantime, some researchers reported that some of the reasons that affect women's decision to work are family and personal duty (EU Labour Force Survey as cited in European Foundation for the Improvement of Living and Working Conditions, 2007, p. 7). These decisions clearly affected the work pattern of women employees and resulted in difficulties in adapting to the work environment of the traditional career pattern or male dominance sector. This is because women tend to do all of the work at home and have less commitment in managing their career or motivation to manage others. Thus, they believe that women are not fit for the job that 
requires them to travel or spend extra hours in the workplace because of family matters (European Foundation for the Improvement of Living and Working Conditions, 2007).

\section{PROBLEM STATEMENT}

Occupational segregation by sex still exists even when women are given the opportunities to work in the maledominated field work (Dainty \& Lingard, 2006). Research shows that the determination of gender inequality in this industry has an effect on women's career development in this industry. Haded though women make up more than 40 percent of the labour force today, not many of them are in the technical fields such as engineering (Husna Johari and colleagues, 2013). The number of women that have graduated from courses related to science, technical and also engineering is high compared to the number of women entering technical jobs using their qualifications (Husna Johari and colleagues, 2013).

Stereotyping has aroused indirect discrimination among female engineers in this sector. They presume that work in construction areas are too heavy for women and they do not perform well in this industry. This kind of perception has become one of the factors that could affect the confidence level of women candidates to get involved in this industry. There are various kinds of challenges that are faced by female engineers in order for them to fulfill their need for success in their career especially for those that are working in the maledominated sector (Thurasamy, Lo, Amri, $\&$ Noor, 2011). Some of the indirect discriminations that exist in this industry is the work life balance issues that influence the decision making of women employees in the construction industry (Dainty \& Lingard, 2006). This factor has restricted women employees from having the right to defend themselves in order for them to stay in this industry and to receive the same benefits as male employees. Therefore, there is a need to conduct this study.

\section{RESEARCH OBJECTIVES}

The main objective of this study is to find out the issues that arise in the construction industry towards the female engineers and how they affect career development and career success among women employees. The specific objectives of this study are:

- To identify the barriers in term of work-life balance that are faced by female engineers;

- To identify the role of gender that is affecting women's career success in the construction industry; and

- To identify other factors that could affect the women's career success in the construction industry.

\section{RESEARCH METHODOLOGY}

This research is designed from a qualitative research approach. An in-depth semi-structured interview approach was carried out in this research in which guided questions were developed. The 
researcher carried out the in-depth interviews. In this in-depth interview session, the focus was on the specific objectives of this research, which were to explore the participants' own opinions or experiences.

\section{Participants}

The recruitment of participants was from various construction organizations in peninsular Malaysia. Due to the small scale of female engineers in private sectors, the number of samples for this study was only five participants (Participant 1, Participant 2, Participant 3, Participant 4, and Participant 5).

\section{Instrument}

The interview schedule was adopted from Salman Azhar and Amos Griffin (2012) and Farah Mukhtar (2012). This interview schedule included a guided question form based on research objectives and questions. The interview approach was an in-depth interview which was held individually with the participants. An in-depth phone interview was carried out and recorded.

\section{Data Analysis}

As data analysis procedure, the researcher applied content analysis method which included four steps in analyzing the data procedures; reading or memoing, describing the context and participants, classifying and also interpreting. In this research, the researcher has undergone these steps: first, the collected data were organized according to types (observer's notes, memo to self, transcripts from interviews), themes and patterns that emerged. Next was the examining of data to provide a more detailed description or information of the setting, participants and also the activities. After that, all of the data were categorized into the themes that have been identified. Lastly was interpreting and synthesising the organized data into a general written conclusion. Then, the results were compared with the information that was collected in the literature review to find similarities or to derive at a new finding between previous and current researches.

\section{FINDINGS AND DISCUSSION}

\section{Barriers between Work-Life Balance}

In this research, the first theme was barriers between work-life balance. It was noticed that some of the significant themes that have been identified was the work-family conflicts, competition among men and women, nature of work and salary. For the work-family conflicts, it has been known that women are bound to the role of mother and this makes it hard for them to focus on both work and family responsibilities. As Participant 1 and Participant 2 responded:-

Participant 1- Offshore makes me difficult to contact with my family because of the slow and sometimes no network at all.

Participant 2 - If we, women want to go far in our career, somehow, we need to sacrifice our family where we are re- 
quired to be far from spouse, parents, children, and life itself.

Women tend to be distracted in work when it comes to family matters. They are said to likely mix the role of employee and mother in the workplace. For example, if anything goes wrong in the family or if any emergency issues that are related to family, especially children, arise, women's attention tend to be distracted and eventually they ask for an emergency leave to handle the situation. It is not that men are not concerned about their family or children, but women, the way they act, are generally affected by their emotions. These role conflicts make it difficult for women to achieve success in their career.

As Participant 4 reported:-

Participant 4 - We, women have to divide our time equally in term of handling both work and family matters. It is not that we been discriminate, but when it comes to family matters, women tend to worry more. Male engineers, they have their wife whom takes care of their children, but we, women have to take care of both.

Participant 5 too, gave similar response:-

Participant 5 - If challenges I would say the responsibilities between work and family. If someone is a single person, I think it wouldn't be a problem. But when she has a family, that would be a little bit difficult in order for her to give time for both.

Only some that are strong enough manage to overcome the situation but some end up withdrawing from their career. As mentioned by Salman Azhar and Amos Griffin (2014), female engineers have problems in balancing their commitment between work and family. Dainty and Lingard (2006) also stated that some of the indirect discriminations that exist in this industry is that there been a proclaimed that life cycle and family needs is influenced the decision making of the women employee that could restrict the development progress for them to stay in the construction industry. Women are proven to care for their families more than their jobs and this would make them to withdraw from this industry.

\section{Role of Gender}

The second theme is competition among men and women in the industry. Construction is known as tough work highly dominated by men. For a woman to enter this industry, she has to work hard or even harder in order for her to be at the same level as a man. One of the participants has mentioned that it was hard for her to shine in this field. As Participant 1 mentioned:-

It is hard for us to shine in this industry because our competitors are so tough.

Participant 3 also gave her point in term of physical strength.

Men always do work better than us in term of their strength. So it is hard for women to compete with men in term of physical strength.

In order to maintain their positions in the male-dominated construction industry, female engineers only have three choices which is to act like a man or 
have a lower goals and expects only for secondary position or give up and move on to work elsewhere (Dainty and colleagues, 2000). Even when women are given the same opportunities, they still have to compete with the 'expert' in this field. Only few women who are really determined manage to surpass men in this industry. Husna Johari and colleagues (2013) mentioned that female engineers that worked in the construction industry found themselves to be survivors in this industry.

Participant $\mathbf{4}$ has pointed strongly that so far I haven't seen any kind of unequal employment at my workplace. We, men and women are treated the same way; if we get a chance to do work at site, then women also be given the chance to go do the site work.

Participant 3 too, conveyed a similar belief:

I don't think so. In my opinion, if men can do it, why not us! It is all depending on us, women; the way we perceive those challenges. So to me, gender is not an issue here.

\section{Other Factors contributing to Career Success}

The third theme is nature of work. An engineer is exposed to too many kinds of unpredictable situations. For example like the field engineer, they are exposed to all kinds of hazardous situations.

Participant 1 mentioned that work as a field engineer is a tough work! We have to go for an offshore, far away from family for a month or months..the work is tough and the environment is not quite supportive for the communication with outside people. When I'm on offshore, I have to stay at other place for a month. So it's quite hard for me to keep in touch with my husband frequently because of the line connection.

Those who are not mentally and physically prepared for any situation that may occur may end up withdrawing from the career or stay on at the lower position. That is the reason men are more compatible of doing this job. Men are known to be physically and mentally strong, so it is easier for them to cope with any situation that might occur.

One of the participants said that she would soon change to another job because of the nature of the work as a field engineer that needed her to often go offshore and the risky environment of her workplace. These points are supported by Madegwa (2011) who said that women employees tend to have difficulties in developing a clear understanding in order to build their strength and see their weaknesses as they are not able to determine the expected outcomes of their roles in the organization. Smith (1991) also stated that women are incapable to do jobs that are dominated by men and therefore they are segregated into lower income occupation.

Based on the collected data that are acquired from the interview sessions, gender-determined factor like discrimination in the workplace between men and women does not exist anymore, at least 
in their current company. Most of the organizations are now implementing equal employment between men and women in the workplace. Hence, this is a new finding for this research. Other researchers explain that one of the challenges that are faced by women employees in the engineering field is discrimination on the perceptions of women's skills and capabilities in doing a maledominance job and this has led to the slow career progression of the women employees (Salman Azhar and Amos Griffin, 2014). Tharenou (1999) also explained that the slow mobility and the differences advancing of the women employees in the organization are that gender differences invest in different human capital result. Women tend to receive a lower advancement in terms of rewards, payment, and job status because they make up a fewer investment than men. But from the data collection, it has been proven that there discrimination among women and men in the workplace does no longer exist.

Finally, support from the top management is crucial. Support from superiors or the management team is important in every organization. They play an important role to make sure that the organization achieves its goals, mission, and vision. Support from them would be very helpful in order for employees to feel motivated and also appreciated. Employees tend to stay in the organization because they get the backup support from the top management as well as their colleagues. Unlike previous research that said that women were segregated from the top management position, one partic- ipant from this research stated that most of the high-level positions in her company were occupied by women.

\section{SUGGESTIONS}

Organizations play an important role in making sure that the environment in the workplace is always conducive for all of their employees to develop their careers to the point that they can succeed. Organizational support makes employees work harder to achieve their goals and not stop in the middle of the road. The management team of an organization can design and carry out a training programme for women employees so that they can improve their skills and can perform better and be as good as men. This will improve their career success and can help them to stay in the profession that they like. Training programmes can help employees to improve their skills better and help them to perform better. For example, teamwork training. Working in a group can improve critical thinking skills and it also helps employees to come out with faster solutions because they are used to working in a group.

A mentoring programme is also a good initiative for women employees to develop their skills by having a mentor who can help them. By having a mentor, an employee can improve her skills better because a mentor can help her by providing guidelines and advices and be her coach at the same time. In most of organizations, this technique is used in order for them to train high-performance workers. This is because a mentor does 
not only focus on the employee's lack of skill about work, but a mentor also acts as a listener if the employee has problems that are not related to work.

\section{CONCLUSION}

This qualitative research has discovered a few challenges that are faced by female engineers in the construction industry. Inflexible working condition and long working hours can cause some difficulties for employees in their effort to maintain a balance between work and family responsibilities. These difficulties can cause stress among the employees and an unhealthy environment at the workplace may be created. Stress can cause other problems such as low self-esteem and difficulty in communicating with others which may eventually affect the performance of the employee. Once an employee cannot cope with the stress anymore, she tends to withdraw from the organization. Married couples may come out with a few strategies like dividing family or home tasks or take turns in carrying out home responsibilities order to adapt to these pressures. However, the nature of work as well as the responsibility of running the daily family chores is a real challenge to the female partner. This is where the top management can play their part. They must support their subordinates so that their employees can focus on the work and give their full commitment. Employee factors like satisfaction can affect work productivity in an organization. When the productivity of women is low, human capital in the labour market could be adversely affected.

\section{REFERENCES}

Altucher, K., \& Williams, L. (2003). Family clocks: Timing parenthood. In P. Moen (Ed.), It's about time: Couples and careers (pp. 49-59). Ithaca, NY: Cornell University Press.

Dainty, A., Neale, R., \& Bagilhole, B. (2000). Comparison of men's and women's career in UK construction industry. ASCE Journal of Professional Issues in Engineering Education and Practice, 126(3), 110-114.

Dainty, A. R. J., \& Lingard, H. (2006). Indirect discrimination in construction organizations and the impact on women's career. Journal of Management in Engineering, 22(3), 108118.

Department of Statistics, Malaysia. (2012). Labour force survey report. Kuala Lumpur, Malaysia.

English, J., Haupt, T. C., \& Smallwood, J. J. (2006). Women, construction and health and safety $(\mathrm{H} \& S)$ : South African and Tanzanian perspectives. Journal of Engineering, Design and Technology, 4(1), 18-28.

European Foundation for the Improvement of Living and Working Conditions. (2007). Gender and career development. Retrieved from http://www.eif.gov.cy/mlsi/dl/gende requality.nsf/0/88AC670378588FC3C2257 9A50037C8AE/\$file/gender_and_c areer_development-eiro.pdf

Farah Mukhtar. (2012). Work life balance and job satisfaction among faculty at Iowa State University. Re- 
trieved from Graduate Theses and Dissertations. (Paper 12791).

Fernando, N. G., Amaratunga, D., \& Haigh, R. (2014). The career advancement of the professional women in the UK construction industry. Journal of Engineering, Design and Technology, 12(1), 53-70.

Fielden, S. L., Davidsn, M. J., Gale, A., \& Davey, C. L. (2001). Women, equality and construction. Journal of Management Development, 20(4), 293-305.

Fouad, N. A., Romila Sigh, Fitzpatrick, M. E., \& Liu, J. P. (2012). Stemming the tide: Why women leave engineering (Unpublished Doctoral Dissertation). University of Wisconsin-Milwaukee, Milwaukee, Wisconsin.

Heilman, M. E. (2001). Description and prescription: how gender stereotypes prevent women's ascent up the organizational ladder. Journal of Social Issues, 57(4), pp. 657-674.

Husna Johari, Norsiah Mat, Norazwa Mat, Siti Norezam Othman, \& Aini Hayati Mohamed. (2013). Exploring career success among female engineers: the Malaysian case. International Journal of Education and Research, 1(11), 1-8.

Kolade, O. J., \& Kehinde, O. (2013). Glass ceiling and women career advancement: Evidence from Nigeria construction Industry. Iranian Journal of Management Studies, 6(1), 79-99.

Kyriakidou, O. (2011). Negotiating gendered identities through the process of identity construction. Equality,
Diversity and Inclusion: An International Journal, 31(1), 27-42.

Madegwa, L. (2011). Challenges of career development faced by women in senior management in the civil service in Kenya. (Unpublished master's thesis). University of Nairobi, Nairobi, Kenya.

Maimunah Ismail, M., \& Mariani Ibrahim, M. (2008). Barriers to career progression faced by women: Evidence from a Malaysian multinational oil company. Gender in Management: An International Journal, 23(1), 51-66.

Miguel, M. M. (1993). Individual definitions of career success: at odds with organizational and social definitions. Career Development International, 9(6), 595-608.

Ministry of Women, Family and Community Development (MWFCD), \& United Nation Development Programme (UNDP). (2014). Study to support the development of national policies and programmes to increase and retain the participation of women in the Malaysian labour force: Key findings and recommendations. Putrajaya, Malaysia.

Reynolds, L. E. (2005). Surrendering the dream: Early career conflict and faculty dissatisfaction thresholds. Journal of Career Development, 32(2), 107-121.

Salman Azhar., \& Amos Griffin, M. K. (2014, March). Women in construction: Successes, challenges and opportunities - A USACE case study. Paper presented at the 50th Associated Schools of Construction Annu- 
al International Conference Proceedings, Blacksburg, Virginia.

Siti Hanisah Tapsir, \& Norliza Mohd Noor. (2015). Female engineers in Malaysia. Retrieved from http://dspace.unimap.edu.my/ dspace/bitstream/123456789/ 13814/1/ Women\%20Engineers\%20in\%20Malaysi a.pdf

Smith, S. A. (1991). Sources of earnings inequality in the black and white female labor forces. The Sociological Quarterly, 32(1), 117-138.

Srivastava, A. (1992). A case study widening access to construction higher education. (Unpublished doctoral thesis). Leeds Metropolitan University, Leeds, England.
Tharenou, P. (1999). Gender Differences in Advancing to the Top. Oxford, England: Blackwell Publishers Ltd.

Thurasamy, R., Lo, May-Chiun. A., Amri, Y., \& Noor, N. (2011). An analysis of career advancement among engineers in manufacturing organizations. International Journal of Commerce and Management, 21(2), 143-157.

Thompson, C. A., Beauvais, L. L., \& Lyness, K. S. (1999). When workfamily benefits are not enough: The influence of work-family culture on benefits utilization, organizational attachment, and work-family conflict. Journal of Vocational Behaviour, 54(1), 392-415. 